\title{
PERIZINAN BERUSAHA TERINTEGRASI SECARA ELEKTRONIK TERHADAP PENYELENGGARAAN PENANAMAN MODAL DI DAERAH
}

\author{
Bambang Arwanto \\ Universitas Narotama Surabaya, Indonesia \\ Email : bambang.arwanto@narotama.ac.id \\ Edi Surohadi \\ Universitas Narotama Surabaya, Indonesia \\ Email : surohadieddy@gmail.com
}

\begin{abstract}
Abstrak
Tulisan ini menggunakan pendekatan perundang-undangan (statute approach), dan pendekatan konseptual (conceptual approach). Fokus pembahasan pada ratio legisdan akibat hukum ditetapkannya Peraturan Pemerintah Nomor 24 Tahun 2018 Tentang Pelayanan Perizinan Berusaha Terintegrasi Secara ElektronikTerhadap Peraturan Daerah Provinsi Jawa Timur. Dimana diketahui bahwa Ratio legis ditetapkannya Peraturan Pemerintah Nomor 24 Tahun 2018 didasarkan pada pertimbangan bahwa Pemerintah Pusat berusaha mengadakan percepatan dan peningkatan penanaman modal dan berusaha, dengan menerapkan pelayanan Perizinan Berusaha Terintegrasi Secara Elektronik dan untuk melaksanakan ketentuan Pasal 25 Undang-Undang Nomor 25 Tahun 2007 tentang Penanaman Modal serta Pasal 6 dan Pasal 7 Undang-Undang Nomor 23 Tahun 2014 tentang Pemerintahan Daerah. Dengan ditetapkannya Peraturan Pemerintah Nomor 24 Tahun 2018 mengakibatkan Peraturan Daerah Provinsi Jawa Timur Nomor 12 Tahun 2013 Tentang Penanaman Modal sebagai dasar penyelenggaraan penanaman modal di Provinsi Jawa Timur bertentangan Perundang Undangan lebih tinggi sehingga perlu diselaraskan dengan Peraturan Pemerintah Nomor 24 Tahun 2018.
\end{abstract}

\section{Kata Kunci: Implikasi; Perizinan; Penanaman Modal.}

\begin{abstract}
This essay uses a statutory approach (statute approach), and a conceptual approach (conceptual approach). The focus of the discussion is ratio legis and the legal consequences of the stipulation of Government Regulation Number 24 of 2018 concerning Electronically Integrated Business Licensing Services to Regional Regulations of East Java Province. Where it is known that the Ratio legis of the stipulation of Government Regulation Number 24 of 2018 is based on the consideration that the Central Government is trying to accelerate and increase investment and business, by implementing Electronic Integrated Business Licensing services and to implement the provisions of Article 25 of Law Number 25 of 2007 concerning Investment and Article 6 and Article 7 of Law Number 23 of 2014 concerning Regional Government. With the enactment of Government Regulation Number 24 of 2018, the Regional Regulation of East Java Province Number 12 of 2013 concerning Investment as the basis for implementing investment in East Java Province contradicts the higher Invitation Law so that it needs to be harmonized with Government Regulation Number 24 of 2018.
\end{abstract}

Keywords: Implication; Licensing; Capital Investment.

\section{A. PENDAHULUAN}

Secara yuridis dalam ketentuan Pasal 16 Undang Undang Nomor 23 Tahun 2014 Tentang Pemerintahan Daerah, Pemerintah Pusat diberikan kewenangan untuk menetapkan norma, standar, prosedur, dan kriteria dalam rangka penyelenggaraan urusan pemerintahan dan melaksanakan pembinaan dan pengawasan terhadap penyelenggaraan urusan pemerintahan 
yang menjadi kewenangan Daerah. Ketentuan tersebut menjadi kewajiban hukum bagi pemerintahan daerah untuk mempedomani segala kebijakan yang ditetapkan Pemerintah Pusat, dalam menyelenggarakan urusan pemerintahan daerah.

Pada Tahun 2018 Pemerintah Pusat menetapkan Peraturan Pemerintah Nomor 24 Tahun 2018 Tentang Pelayanan Perizinan Berusaha Terintegrasi Secara Elektronik (Peraturan Pemerintah Nomor 24 Tahun 2018). Dimana dalam ketentuan Pasal 2 dan Pasal 3 Peraturan Pemerintah tersebut menyatakan bahwa sebagai memegang kekuasaan pemerintahan yang diuraikan dalam berbagai urusan pemerintahan dan pelaksanaannya dilakukan oleh kementerian negara dan penyelenggara Pemerintahan Daerah. Urusan pemerintahan tersebut mencakup kewenangan pemberian Perizinan Berusaha, fasilitas, dan/atau kemudahan untuk pelaksanaan berusaha. Dimana Pemerintah Pusat menetapkan kebijakan penyelenggaraan kewenangan pemberian Perizinan Berusaha sebagaimana diatur dalam Peraturan Pemerintah ini dan peraturan perundang-undangan lainnya yang terkait.

Peraturan Pemerintah Nomor 24 Tahun 2018, ini, mengatur ketentuan mengenai: a. jenis, pemohon, dan penerbit perizinan berusaha;

b. pelaksanaan perizinan berusaha;

g. insentif atau disinsentif pelaksanaan perizinan beru-

c. reformasi perizinan berusaha sektor;

d. sistem OSS;

e. lembaga OSS; saha melalui OSS;

h. penyelesaian permasalahan dan hambatan perizinan berusaha melalui OSS; dan

i. sanksi.

Beberapa ketentuan dalam Peraturan Pemerintah Nomor 24 Tahun 2018 menyatakan tidak berlaku beberapa ketentuan yang mengatur tentang perizinan, misalnya dalam ketentuan Pasal 46, Pasal 71 dan dalam Pasal 76. Dalam Peraturan Pemerintah Nomor 24 Tahun 2018, menyatakan bahwa pada saat Peraturan Pemerintah ini mulai berlaku, ketentuan dalam Peraturan Pemerintah Nomor 15 Tahun 2010 tentang Penyelenggaraan Penataan Ruang yang mengatur mengenai Izin Lokasi, Peraturan Pemerintah Nomor 27 Tahun 2012 tentang Izin Lingkungan yang mengatur mengenai penyusunan dokumen Amdal dan UKL-UPL, penilaian Amdal dan pemeriksaan UKL-UPL, serta permohonan dan penerbitan Izin Lingkungan. Peraturan Pemerintah Nomor 36 Tahun 2005 tentang Peraturan Pelaksanaan Undang-Undang Nomor 28 Tahun 2002 tentang Bangunan Gedung yang mengatur mengenai IMB dan sertifikat laik fungsi dinyatakan masih tetap berlaku sepanjang tidak bertentangan dengan ketentuan dalam Peraturan Pemerintah ini atau tidak diatur secara khusus dalam Peraturan Pemerintah ini.

Selanjutnya dalam ketentuan Pasal 85 diatur mengenai reformasi pengaturan Perizinan Berusaha terhadap Perizinan Berusaha pada 20 sektor sebagaimana disebutkan dibawah ini :
a. sektor ketenagalistrikan;
b. sektor pertanian;
c. sektor lingkungan hidup dan kehutanan;
d. sektor pekerjaan umum dan perumahan rakyat;
e. sektor kelautan dan perikanan;
f. sektor kesehatan;
g. sektor obat dan makanan;
h. sektor perindustrian;
i. sektor Perdagangan;
j. sektor perhubungan;
k. sektor komunikasi dan informatika

1. sektor keuangan;

m. sektor pariwisata;

n. sektor pendidikan dan kebudayaan;

o. sektor pendidikan tinggi;

p. sektor agama dan keagamaan;

q. sektor ketenagakerjaan;

r. sektor kepolisian;

s. sektor perkoperasian dan usaha mikro, kecil, menengah; dan

t. sektor ketenaganukliran. 
Ketentuan Perizinan Berusaha pada sektor sebagaimana dimaksud diatas yang telah ada sebelum berlakunya Peraturan Pemerintah ini diatur dan dilaksanakan sesuai dengan ketentuan Peraturan Pemerintah ini dan memerintahkan kepada Gubernur, mencabut dan menyatakan tidak berlaku seluruh peraturan dan/atau keputusan yang mengatur mengenai norma, standar, prosedur, dan kriteria Perizinan Berusaha yang menjadi kewenangannya, yang tidak sesuai dengan Peraturan Pemerintah ini yang ditetapkan paling lama 15 (lima belas) hari sejak diundangkannya Peraturan Pemerintah ini. Apabila Gubernur tidak memberikan pelayanan pemenuhan komitmen izin usaha dan/atau izin komersial atau operasional sesuai OSS kepada pelaku usaha yang telah memenuhi persyaratan berdasarkan ketentuan Peraturan Pemerintah ini dan peraturan perundang-undangan terkait akan dikenai sanksi.

Dari aspek yuridis pengaturan pelayanan perizinan berusaha terintegrasi secara elektronik dalam Peraturan Pemerintah Nomor 24 Tahun 2018, menimbulkan permasalahan hukum dalam penyelenggaraan pemerintahan daerah, khususnya Daerah Provinsi Jawa Timur. Hal ini disebabkan karena terjadinya inkonsistensi antara pengaturan system pelayanan perizinan berusaha di Daerah Provinsi Jawa Timur dengan pengaturan perizinan berusaha terintegrasi secara elektronik sebagaimana diatur dalam Peraturan Pemerintah Nomor 24 Tahun 2018, baik dari aspek pengaturan kewenangan kelembagaan, jenis dan managemen perizinan berusaha yang diatur dalam Peraturan Daerah Provinsi Jawa Timur misalnya dalam Peraturan Daerah Nomor 12 Tahun 2013 Tentang Penanaman Modal.

Berdasarkan permasalahan hukum pada pengaturan Perizinan Berusaha Terintegrasi secara Elektronik dalam Peraturan Pemerintah Nomor 24 Tahun 2018 sebagaimana diuraikan diatas dengan system pelayanan perizinan berusaha di Daerah Provinsi Jawa Timur menjadi dasar Penyusunan Jurnal Implikasi Ditetapkannya Peraturan Pemerintah Nomor 24 Tahun 2018 Tentang Perizinan Berusaha Terintegrasi Secara Elektronik Terhadap Penyelenggaraan Penanaman Modal Di Daerah Provinsi Jawa Timur. Dengan fokus permasalahan pada Ratio Legis ditetapkannya Peraturan Pemerintah Nomor 24 Tahun 2018 Tentang Pelayanan Perizinan Berusaha Terintegrasi Secara Elektronik dan Akibat Hukum Ditetapkannya Peraturan Pemerintah Nomor 24 Tahun 2018 Tentang Pelayanan Perizinan Berusaha Terintegrasi Secara Elektronik Terhadap Penyelenggaraan Penanaman Modal Provinsi Jawa Timur.

\section{B. METODE PENELITIAN}

Jenis penelitian yang digunakan penulis adalah penelitian hukum normatif. Penelitian hukum normatif adalah penelitian hukum yang meletakkan hukum sebagai sebuah bangunan sistem norma. Dengan metode pendekatan : Pendekatan perundang-undangan (statute approach), Pendekatan konspetual (conceptual approach), dan Pendekatan kasus (case approach).

\section{PEMBAHASAN}

\subsection{Ratio Legis Pembentukan Peraturan Pemerintah Nomor 24 Tahun 2018 Tentang Pelayanan Perizinan Berusaha Terintegrasi Secara Elektronik.}

Berdasarkan ketentuan Pasal 7 ayat (2) dan Pasal 8 ayat (2) Undang Undang Nomor 12 Tahun 2011, Peraturan Pemerintah memiliki hierarki dibawah Undang-Undang/Peraturan Pemerintah Pengganti Undang-Undang dan memiliki hierarki diatas Peraturan Presiden dan Peraturan Daerah Provinsi dan Peraturan Daerah Kabupaten/Kota. Maka berdasarkan prinsip pengakuan keberadaan dan kekuatan hukum mengikatnya suatu peraturan perundang undangan, UndangUndang memiliki berkekuatan hukum lebih kuat dan mengikat dan diakui keberadaannya daripada Peraturan Pemerintah yang berkedudukan dibawahnya, sebaliknya apabila Peraturan Pemerintah dibandingkan dengan beberapa jenis Peraturan perundang Undangan dibawahnya 
misalya dengan Peraturan Presiden dan Peraturan Daerah, maka Peraturan Pemerintah memiliki kekuatan hukum lebih kuat dan mengikat serta diakui keberadaannya daripada Peraturan Presiden dan Peraturan Daerah Provinsi dan Peraturan Daerah Kabupaten/Kota.

Dengan demikian berdasarkan pada kedudukan hierarki Peraturan Pemerintah Nomor 24 Tahun 2018 berada dibawah Undang Undang, maka secara hukum Peraturan Pemerintah tersebut tidak diperkenankan mengatur materi muatan yang bertentangan dengan Peraturan Perundang Undangan yang berkedudukan lebih tinggi diatasnya dan kepentingan umum. Apabila materi muatan Peraturan Pemerintah Nomor 24 Tahun 2018 bertentangan dengan Peraturan Perundang Undangan yang berkedudukan lebih tinggi diatasnya dan kepentingan umum dapat berakibat secara hukum Peraturan Pemerintah Nomor 24 Tahun 2018 dapat dibatalkan (nietigeverbaar) atau batal demi hukum (rechtsnietige). ${ }^{1}$

Berkaitan dengan Ratio Legis Pembentukan Peraturan Pemerintah Nomor 24 Tahun 2018 Tentang Pelayanan Perizinan Berusaha Terintegrasi Secara Elektronik yang ditetapkan dan diundangkan pada tanggal 21 Juni 2018 ini. Dapat kita ketemukan dalam konsideran Peraturan Pemerintah Nomor 24 Tahun 2018, dimana dinyatakan bahwa pembentukan Peraturan Pemerintah Republik Indonesia Nomor 24 Tahun 2018 dibentuk berdasarkan pada 2 (dua) pertimbangan yakni dalam rangka percepatan dan peningkatan penanaman modal dan berusaha dan untuk melaksanakan ketentuan Pasal 25 Undang-Undang Nomor 25 Tahun 2007 Tentang Penanaman Modal serta Pasal 6 dan Pasal 7 Undang-Undang Nomor 23 Tahun 2014 Tentang Pemerintahan Daerah.

Pertama, dalam rangka percepatan dan peningkatan penanaman modal dan berusaha.Secara normative kebijakan hukum ini berhubungan pula dengan ditetapkan kebijakan ekonomi makro dalam Rencana Pembangunan Jangka Menengah Nasional 2015-2019 (RPJMN 2015-2019) tentang target Pemerintah memproyeksikan pertumbuhan ekonomi rata-rata 7,0\%, tingkat inflasi rata rata $4,0 \%$ dan nilai tukar rata-rata $\mathrm{Rp} 11.900$. Untuk mendukung pertumbuhan ekonomi tersebut, Pemerintah membutuhkan total investasi (PMTB) Rp 22.534 triliun atau meningkat hampir dua kali lipat dibandingkan dengan periode 5 (lima) tahun sebelumnya (2010-2014).

Kebijakan hukum tersebut tersebut menjadi dasar hukum bagi Pemerintah mengadakan reformasi arah kebijakan dan Strategi penguatan investasi nasional, melalui dua pilar kebijakan yaitupeningkatan iklim investasi daniklim usaha untuk meningkatkan efisiensi proses perijinan bisnis; dan Peningkatan Investasi yang inklusif terutama dari investor domestik. Kedua pilar kebijakan ini akan dilakukan secara terintegrasi baik di tingkat pusat maupun di daerah.Arah kebijakan yang ditempuh dalam pilar pertama yakni penguatan investasi adalah menciptakan iklim investasi dan iklim usaha yang lebih berdaya saing, baik di tingkat pusat maupun daerah, yang dapat meningkatkan efisiensi proses perijinan, meningkatkan kepastian berinvestasi dan berusaha di Indonesia, serta mendorong persaingan usaha yang lebih sehat dan berkeadilan.

Untuk merealisasikan kebijakan ekonomi ini Pemerintah Pusat menetapkan strategi yang harus ditempuh, dengan beberapa cara, antara lain: ${ }^{2}$

1. Peningkatan kepastian hukum terkait investasi dan usaha, yang terutama dilakukan melalui:

a. Sinkronisasi dan harmonisasi peraturan pusat dan daerah agar kebijakan yang diterapkan oleh Pemerintah Daerah dapat selaras dengan kebijakan pemerintah pusat. Salah satu upayanya adalah dengan penyusunan peta jalan harmonisasi regulasi investasi;

b. Penghapusan regulasi dan peraturan di pusat dan daerah yangmenghambat danmempersulit dunia usaha untuk berinvestasi dan berusaha;

${ }^{1}$ Pasal 9 ayat (2) Undang Undang Nomor 12 Tahun 2011

${ }^{2}$ Rencana Pembangunan Jangka Menengah Nasional 2015-2019. Hlm. 106. 
c. Penghapusan rente ekonomi yang menyebabkan tingginya biaya perijinan, baik di pusat maupun di daerah;

d. Penyediaan tata ruang wilayah Kabupaten/Kota yang telah dijabarkan ke dalam Rencana Detail Tata Ruang (RDTR) untuk kepastian perijinan lokasi usaha dan investasi.

2. Pendirian Pelayanan Terpadu Satu Pintu-tingkat Pusat (PTSP-Pusat), untuk menyatukan perijinantingkatpusatpadasatutempatlayananperijinan.Adapunlangkahyangakandilakukan, antara lain adalah:

a. Pengembangan kelembagaan PTSP-Pusat;

b. Penyederhanaan dan standarisasi prosedur, pengembangan proses perijinan secara paralel untukmenghemat waktu, serta pengembangan layanan pengaduan permasalahan perijinan;

c. Penciptaan transparansi dan akuntabilitas proses perijinan, sehingga dapat meningkatkan kepastian waktu dan kredibilitas layanan;

d. Pengembangan tracking system perijinan di PTSP-Pusat;

3. Pemberian insentif dan fasilitasi investasi (berupa: insentif fiskal dan non fiskal) yang lebih selektif dan proses yang transparan;

4. Pendirian Forum Investasi, yang beranggotakan lintas kementerian dan lintas pemangku kepentingan yang secara rutin mengadakan pertemuan untuk memonitor, mengatasi permasalahan investasi, dan mencarikan solusi terbaik agar dapat terus menjaga iklim investasi dan iklim usaha yang kondusif bagi pelaku usaha dan investor.

Berdasarkan data berkurangnya penanaman modal langsung oleh investor domestik pada triwulan II 2017 cukup mengkhawatirkan. Ketidak mampuan pemenuhan proyeksi pertumbuhan ekonomi yang direncanakan, dikarenakan pertumbuhan investasi secara keseluruhan yang tidak maksimal dengan mengingat proyeksi pertumbuhan ekonomi pada Tahun 2018 sebanyak 5,1 $5,5 \% .{ }^{3}$ yang senyatanya tidak memenuhi proyeksikan pertumbuhan ekonomi yang ditargetkan dalam kerangka ekonomi makro RPJMN 2015-2019 dangan rata-rata 7,0\%, tingkat inflasi ratarata $4,0 \%$ dan nilai tukar rata-rata $\mathrm{Rp} 11.900 .{ }^{4}$

Ada beberapa permasalahan yang tenggarai sebagai penyebab ketidak mampuan pemenuhan proyeksi pertumbuhan ekonomi yang direncanakan, antara lain: ${ }^{5}$

1. Dipengaruhi oleh rendahnya investasi sektor swasta, baik di sektor infrastruktur maupun sektor lainnya, akibat dominannya peran perusahaan milik negara, Hal ini berdampak negatif pada pencapaian target pertumbuhan ekonomi selama sisa pemerintahan Presiden Jokowi. dengan upaya melibatkan sektor swasta dalam pembiayaan infrastruktur dianggap sangat penting dengan keterbatasan kemampuan anggaran negara untuk mencakup semua pendanaan infrastruktur serta keterbatasan atas keberlanjutan ambisi pemerintah untuk mengembangkan infrastruktur yang dipimpin oleh BUMN; ${ }^{6}$ dan

2. Hambatan yang bersifat struktural untuk menarik sektor swasta adalah masalah dari persepsi kepastian hukum mengenai peraturan yang diterapkan, terutama persepsi masing-masing investor mengenai kemampuan pemerintah untuk menghormati asas kesucian kontrak dan tidak terlalu sering mengubah peraturan, yang akan menimbulkan risiko tak terduga pada proyeksi pendapatan investor. Sehingga mengurangi minat sektor swasta untuk berpartisipasi dalam pembangunan infrastruktur.

${ }^{3}$ Bank Indonesia.(2018). Pertumbuhan Ekonomi. Jakarta: hlm. 1.

${ }^{4}$ Ibid.

${ }^{5}$ LPEM FEB UI.(2018). Seri Analisis Makroekonomi Indonesia Economic Outlook, Jakarta: hlm. 1.

${ }^{6}$ Seri Analisis Makroekonomi Indonesia Economic Outlook 2018 
Undang Undang Nomor 25 Tahun 2007 Tentang Penanaman Modal, telah mengembangkan suatu system perizinan yang tujuan utamanya diarahkan kepada terciptanya kemudahan pelayanan perizinan investasi baik asing maupun dalam negeri, dengan tidak mengurangi syarat-syarat yang harus dipenuhi dengan menerapkan konsep one roof service system dengan bertumpu kepada one door service system. Namun konsep pelayanan perizinan tersebut tidak tidak banyak membawa perubahan pada level bawah, dimana investor masih merasakan prosedur yang berbelit-belit seperti persyaratan, waktu dan biaya yang harus dikeluarkan oleh investor tidak dapat diukur atau dipastikan.

Permasalahan tersebut menjadi dasar perubahan paradigma pelayanan perizinan khususnya pelayanan perizinan berinvestasi terintegrasi secara elektronik, agar tercipta prosedur perizinan berinvestasi yang dapat dikategorikan murah, cepat, dan jelas sesuai dengan standar pelayanan public yang telah ditetapkan. Dengan kata lain pelayanan perizinan di daerah sesuai dengan prosedur, syarat dan ketentuan yang diadakan. Untuk tercipta persepsi yang sama dalam pemberian pelayanan baik pada dasar hukum pemberian pelayanan, jenis, persyaratan, biaya yang harus dikeluarkan dan lamanya pelayanan diberikan.

Dengan adanya standarisasi pelayanan public pemberian pelayanan perizinan berusaha terintegrasi secara secara elektronik tentu saja akan diperoleh system yang baku dan berkepastian, sehingga investor baik asing maupun dalam negeri dapat mengukur tingkat aksessebilitas pelayanan yang diberikan oleh penyelenggara investasi. Disinilah diperlukan peranan dan fungsi kelembagaan pelayanan perizinan khususnya komitmen penyelenggara investasi di daerah dalam hal ini guna mengatur dan menentukan suatu standarisasi pelayanan perizinan investasi, agar diperoleh kepastian hukum dalam pemberian perizinan, sehingga pihak investor dapat mengaplikasikan modalnya dengan lancer dan terukur. Tanpa adanya standarisasi pelayanan perizinan yang diadakan dalam sebuah pedoman umum prosedur standar pelayanan tentu saja akan membawa implikasi pada aplikasi investasi yang umumnya dikeluhkan oleh para investor dengan tercipta ekonomi biaya tinggi (high cost economy).

Ditetapkannya Peraturan Pemerintah Nomor 24 Tahun 2018 atas dasar pertimbangan dalam rangka percepatan dan peningkatan penanaman modal dan berusaha, dengan menerapkan pelayanan perizinan berusaha terintegrasi secara elektronik tidak terlepas dari adanya komitmen pemerintah pusat untuk membentuk kebijakan yang memperkuat daya saing dan iklim usaha dalam prospek pemulihan ekonomi, baik dari sisi investasi, ekspor maupun struktur lapangan usaha, yang diperkirakan dapat menjadi basis berlanjutnya proses pemulihan ekonomi ke depan.

Hal ini tercantum dalam penjelasan umum Peraturan Pemerintah Republik Indonesia Nomor 24 Tahun 2018 dinyatakan bahwa Dalam rangka percepatan dan peningkatan penanaman modal dan berusaha, Perizinan Berusaha yang diterbitkan oleh kementerian/lembaga dan Pemerintah Daerah untuk memulai, melaksanakan, dan mengembangkan usaha dan/atau kegiatan, perlu ditata kembali agar menjadi pendukung dan bukan sebaliknya menjadi hambatan perkembangan usaha dan/atau kegiatan. Penataan kembali dilakukan pada sistem pelayanan, dan regulasi sesuai dengan tuntutan dunia usaha, perkembangan teknologi, dan persaingan global.Penataan kembali sistem pelayanan dilakukan terutama pada Pelayanan Terpadu Satu Pintu (PTSP) pada Pemerintah Pusat dan Pemerintah Daerah yang disempurnakan menjadi lebih efisien, melayani, dan modern. Salah satunya yang paling signifikan adalah penyediaan sistem Pelayanan Perizinan Berusaha Terintegrasi Secara Elektronik (Online Single Submission-OSS).

Kedua, untuk melaksanakan ketentuan Pasal 25 Undang-Undang Nomor 25 Tahun 2007 Tentang Penanaman Modal serta Pasal 6 Dan Pasal 7 Undang-Undang Nomor 23 Tahun 2014 Tentang Pemerintahan Daerah.Secara yuridis dibentuknya Peraturan Pemerintah Nomor 24 Tahun 2018, difungsikan untuk menjalankan ketentuan Pasal 25 Undang-Undang Nomor 25 
Tahun 2007 Tentang Penanaman Modal serta Pasal 6 dan Pasal 7 Undang-Undang Nomor 23 Tahun 2014 Tentang Pemerintahan Daerah. Berdasarkan ketentuan Pasal 6 dan Pasal 7 UndangUndang Nomor 23 Tahun 2014, Pemerintah menunjuk dasar yuridis kewenangan Pemerintah Pusat dalam hal ini adalah Presiden untuk menetapkan kebijakan hukum sebagai dasar dalam menyelenggarakan urusan pemerintahan dan melakukan pembinaan dan pengawasan terhadap penyelenggaraan urusan pemerintahan Daerah yang dilakukan oleh Pemerintah Daerah dan DPRD. Hal ini dikarenakan Presiden sebagai pemegang tanggung jawab dan tanggung gugat akhir atas penyelenggaraan urusan pemerintahan yang dilaksanakan oleh Pemerintah Pusat maupun Pemerintahan di Daerah.

Sedangkan Pembentukan Peraturan Pemerintah Nomor 24 Tahun 2018 dengan berdasarkan pada ketentuan Pasal 25 Undang-Undang Nomor 25 Tahun 2007 Tentang Penanaman Modal selaras dengan ketentuan Pasal 6 dan Pasal 7 Undang-Undang Nomor 23 Tahun 2014, dimana kepada Penanam modal yang melakukan penanaman modal di Indonesia harus sesuai dengan ketentuan Undang-Undang Nomor 25 Tahun 2007 yakni Penanaman modal dalam negeri dapat dilakukan dalam bentuk badan usaha yang berbentuk badan hukum, tidak berbadan hukum atau usaha perseorangan, sementara Penanaman modal asing wajib dalam bentuk perseroan terbatas berdasarkan hukum Indonesia dan berkedudukan di dalam wilayah Negara Republik Indonesia, kecuali ditentukan lain oleh undang-undang.

Terhadap pengesahan pendirian badan usaha penanaman modal dalam negeri yang berbentuk badan hukum atau tidak berbadan hukum dan Pengesahan pendirian badan usaha penanaman modal asing yang berbentuk perseroan terbatas dilakukan sesuai dengan ketentuan peraturan perundang-undangan. Selain itu dalam undang undang tersebut dinyatakan bahwa bagi Perusahaan penanaman modal yang akan melakukan kegiatan usaha wajib memperoleh izin sesuai dengan ketentuan peraturan perundang-undangan dari instansi yang memiliki kewenangan, kecuali ditentukan lain dalam undang-undang.

Izin dimaksud diperoleh melalui Pelayanan Terpadu Satu Pintu (PTSP) yang bertujuan membantu penanam modal dalam memperoleh kemudahan pelayanan, fasilitas fiskal, dan informasi mengenai penanaman modal.Pelayanan terpadu satu pintu dilakukan oleh lembaga atau instansi yang berwenang di bidang penanaman modal yang mendapat pendelegasian atau pelimpahan wewenang dari lembaga atau instansi yang memiliki kewenangan perizinan dan nonperizinan di tingkat pusat atau lembaga atau instansi yang berwenang mengeluarkan perizinan dan nonperizinan di Provinsi atau Kabupaten/Kota.

Dengan mengacu pada Rencana Pembangunan Jangka Menengah Nasional 2015-2019, bahwa Penguatan kelembagaan pelayanan perizinan terpadu satu pintu tingkat pusat (PTSP Pusat) yang dilengkapi dengan online tracking system dan transparansi informasi tahapan proses, lama waktu guna meningkatkan iklim investasi dan iklim usaha yang lebih kondusif sebagai prioritas penguatan kerangka kelembagaan dan menjadi tugas BKPM.

Sebelumnya berdasarkan pada Peraturan Presiden Nomor 97 Tahun 2014 tentang Penyelenggaraan Pelayanan Terpadu Satu Pintu, PTSP ditujukan untuk mendekatkan dan meningkatkan pelayanan kepada masyarakat serta memperpendek proses pelayanan guna mewujudkan pelayanan yang cepat, mudah, murah, transparan, pasti, dan terjangkau. Peraturan Presiden ini bertujuan untuk menghilangkan dualisme kelembagaan antara Perangkat Daerah di bidang Pelayanan Penanaman Modal (PDPPM) Provinsi dan Perangkat Daerah di bidang Penanaman Modal. Selain itu, dalam Peraturan Presiden Nomor 97 Tahun 2014 diatur pelimpahan atau pendelegasian kewenangan pemberian izin usaha oleh Menteri/Kepala Lembaga kepada Kepala BKPM, semua K/L menempatkan pejabat penghubung pada PTSP Pusat di BKPM untuk memproses perizinan dan memberikan pelayanan informasi. Dengan demikian, BKPM menangani izin prinsip, Angka Pengenal Impor-Produsen (API-P), Angka 
Pengenal Importir-Umum (API-U), fasilitas bea masuk, dan fasilitas perpajakan serta izin usaha yang baru dilimpahkan atau didelegasikan oleh $\mathrm{K} / \mathrm{L}$.

Upaya yang dilakukan BKPM dalam rangka perbaikan iklim penanaman modal antara lain:

1. Mendorong terciptanya kepastian hukum melalui penyederhanaan dan harmonisasi peraturan terkait penanaman modal (deregulasi peraturan);

2. Memberikan kemudahan pelayanan perizinan dan nonperizinan penanaman modal melalui penyelenggaraan PTSP di bidang penanaman modal baik di Tingkat Pusat (BKPM), Provinsi dan Kabupaten/Kota; dan

3. Mengembangkan Sistem Pelayanan Informasi dan Perizinan Investasi Secara Elektronik (SPIPISE) dan penyediaan online tracking system. ${ }^{7}$

Sebagaimana diuraikan dalam sub bab Dalam Rangka Percepatan Dan Peningkatan Penanaman Modal Dan Berusaha,bahwa kebijakan hukum ditetapkannyaPeraturan Presiden Nomor 97 Tahun 2014 tentang Penyelenggaraan Pelayanan Terpadu Satu Pintu dipandang belum mampu merealisasikan proyeksi pertumbuhan ekonomi yang direncanakan dalam kerangka ekonomi makro RPJMN 2015-2019, yakni pertumbuhan ekonomi dangan rata-rata $7,0 \%$, tingkat inflasi rata-rata 4,0\% dan nilai tukar rata-rata $\mathrm{Rp} 11.900 .{ }^{8}$ Dimana mengingat proyeksi pertumbuhan ekonomi pada Tahun 2018 sebanyak 5,1 - 5,5\%. ${ }^{9}$ Untuk menanggapi kondisi tersebut pada tahun 2018, Sebelum ditetapkannya Peraturan Pemerintah Nomor 24 Tahun 2018 Tentang Pelayanan Perizinan Terintegrasi Secara Elektronik, pada tahun 2017 Presiden Republik Indonesia terlebih dahulu menetapkan Peraturan Presiden Republik Indonesia Nomor 91 Tahun 2017 Tentang Percepatan Pelaksanaan Berusaha.

Peraturan Pemerintah ini lahir disebabkan beberapa pertimbangan antara lain:

a. adanya perkembanganjumlah, penyebaran, skala, maupun efisiensikegiatanusahamerupakan penentu utama pertumbuhan ekonomi, penciptaan lapangan kerja, pengurangan kemiskinan serta ketimpangan antar daerah maupun antar kelompok pendapatan;

b. perizinan berusaha yang diterbitkan oleh kementerian/lembaga dan pemerintah daerah untuk memulai, melaksanakan, dan mengembangkan kegiatan usaha, perlu ditata kembali agar menjadi pendukung dan bukan sebaliknya menjadi hambatan perkembangan kegiatan usaha;

c. bahwa penataan kembali diwujudkan dalam bentuk pelayanan, pengawalan (end to end), dan peran aktif penyelesaian hambatan pelaksanaan berusaha melalui pembentukan Satuan Tugas pada tingkat nasional, kementerian/ lembaga, daerah provinsi, dan daerah kabupaten/ kota;

d. dalamrangkapercepatanpelaksanaanberusahadikawasanekonomikhusus, kawasanPeraturan Daerahgangan bebas dan pelabuhan bebas, kawasan industri, dan/atau kawasan pariwisata sudah dapat dilaksanakan dalam bentuk pemenuhan persyaratan (checklist); dan

e. untuk penyederhanaan lebih lanjut perlu diatur dan ditetapkan kembali standar pelayanan pada kementerian/lembaga, daerah provinsi, dan daerah kabupaten/kota, melalui reformasi peraturan yang diperlukan untuk melaksanakan kegiatan usaha; serta

f. untuk mempercepat dan mempermudah pelayanan untuk berusaha perlu menerapkan penggunaan teknologi informasi melalui Sistem Perizinan Berusaha Terintegrasi Secara Elektronik (Online Single Submission).

Berkaitan dengan pertimbangan pada huruf f Peraturan Presiden Republik Indonesia Nomor 91 Tahun 2017 Tentang Percepatan Pelaksanaan Berusaha, tersebut.Presiden menindak

\footnotetext{
${ }^{7}$ Rencana Strategis Badan Koordinasi Penanaman Modal Tahun 2015-2019, hlm. 5.

${ }^{8}$ Ibid.

${ }^{9}$ Bank Indonesia.(2018).Pertumbuhan Ekonomi. Jakarta: hlm. 1.
} 
lanjuti dengan mengeluarkan Peraturan Pemerintah Nomor 24 Tahun 2018 Tentang Pelayanan Perizinan Terintegrasi Secara Elektronik yang dijadikan sebagai sarana reformasi perizinan di Indonesia.Dalam Peraturan Pemerintah tersebut diadakan reformasi system perizinan berusaha yang terintegrasi secara elektronik, meliputi Institusi dan manajemen perizinan berusaha secara elektronik dan termasuk penggabungan dan penghapusan beberapa jenis perizinan.

Dalam Penjelasan Umum Atas Peraturan Pemerintah Republik Indonesia Nomor 24 Tahun 2018, secara tegas dinyatakan bahwa Penataan kembali sistem pelayanan dilakukan terutama pada Pelayanan Terpadu Satu Pintu (PTSP) pada Pemerintah Pusat dan Pemerintah Daerah yang disempurnakan menjadi lebih efisien, melayani, dan modern. Sehingga mendasari Penyempurnaan regulasi yang dituangan dalam Peraturan Pemerintah Nomor 24 tahun 2018 tentang Pelayanan Perizinan Berusaha Terintegrasi Secara Elektronik, meliputi ketentuan mengenai: 1. jenis, pemohon, dan penerbit Perizinan Berusaha; 2. pelaksanaan Perizinan Berusaha; 3. reformasi Perizinan Berusaha sektor; 4. sistem OSS; 5. Lembaga OSS; 6. pendanaan OSS; 7. insentif atau disinsentif pelaksanaan Perizinan Berusaha melalui OSS; 8. penyelesaian permasalahan dan hambatan Perizinan Berusaha melalui OSS; dan 9. sanksi. Berdasarkan pada 2 (dua) pertimbangan di atas, menjadi dasar ditetapkan Peraturan Pemerintah Nomor 24 Tahun 2018 tentang Pelayanan Perizinan Berusaha Terintegrasi Secara Elektronik.

\subsection{Akibat Hukum Ditetapkannya Peraturan Pemerintah Nomor 24 Tahun 2018 Tentang Pelayanan Perizinan Berusaha Terintegrasi Secara Elektronik Terhadap Penyelenggara- an Penanaman Modal di Provinsi Jawa Timur.}

Kondisi Pertumbuhan Perekonomian daerah Provinsi Jawa Timur pada tahun 2017 tumbuh sebesar 5,45 persen. Pertumbuhan positif terjadi pada seluruh lapangan usaha. Penyediaan Akomodasi dan Makan Minum mengalami pertumbuhan tertinggi sebesar 7,91 persen; diikuti Pertambangan dan Penggalian sebesar 7,47 persen; dan Informasi dan Komunikasi sebesar 6,92 persen. Struktur perekonomian Jawa Timur menurut lapangan usaha tahun 2017 didominasi oleh tiga lapangan usaha utama yaitu Industri Pengolahan dengan kontribusi sebesar 29,03 persen; Pertanian, Kehutanan dan Perikanan sebesar 12,80 persen; dan Peraturan Daerahgangan Besar-Eceran dan Reparasi Mobil-Sepeda Motor sebesar 18,18 persen.

Dalam sektor InvestasiTotal Nilai Izin Prinsip Tahun $2017^{10}$ sebesar Rp. 328,15 Trilyun, meningkat sebesar 434.19\% dari Tahun 2016 (Rp. 61,43 T) yang terdiri dari:

PMA : 330 Proyek ; Rp. 269,87 Trilyun ; 40.125 Tng Kerja;

PMDN : 841 Proyek; Rp. 58,28 Trilyun ; 48.180 Tng Kerja; dan

PMA \& PMDN : 1.171 Proyek ; Rp. 328,15 Trilyun ; 88.395 Tng Kerja.

Dimana Total Realisasi Investasi Tahun 2017 sebesar Rp. 152,39 Trilyun, dengan capaian 98,29\% dari s/d Tahun 2016 (Rp. 155,04 T) dengan:

PMA : 2.527 Proyek ; Rp. 21,49 Trilyun ; 78.496 Tng Kerja;

PMDN : 2.165 Proyek; Rp. 45,04 Trilyun ; 69.290 Tng Kerja;

PMA \& PMDN : 4.692 Proyek ; Rp. 66,53 Trilyun ; 147.786 Tng Kerja;

PMDN Non Fas. : : 129.260 Unit Usaha ; Rp. 85,86 Trilyun ; 451.076 Tng Kerja.

Kinerja Pelayanan Perizinan Terpadu DPMPTSP Provinsi Jawa Timur pada tahun 2017 : 38.545 izin/non izin dengan nilai investasi Rp. 41,46 Trilyun. Dengan Prosentase penerbitan izin/non izin s/d Tahun 2017:

a. Sektor Kesehatan : $73,20 \%$;

b. Sektor Peternakan : $5,85 \%$

c. Sektor Energi Sumber Daya Mineral : 4,92\%

${ }^{10}$ Laporan Keterangan Pertanggungjawaban Gubernur Kepada DPRD Provinsi Jawa Timur Akhir Tahun Anggaran 2017, hlm. 51.

212 Bambang Arwanto \& Edi Surohadi | Implikasi Ditetapkannya Peraturan Pemerintah 
d. Sektor Perindustrian dan Peraturan Daerahgangan: 3,77\%

e. Sektor Ketenagakerjaan \& Kependudukan : 3,53\% dan

f. 12 sektor lainnya : $8,73 \%$.

Sampai dengan Tahun 2017 telah menerbitkan Izin Prinsip PMDN : 147 izin, nilai investasi : Rp. 28.049.312.322.683, Izin Usaha PMDN : 72 izin, nilai investasi : Rp. 11.274.489.195.664 dan Izin PMDN Non Fasilitas : 153 izin, nilai investasi : Rp. 2.135.812.479.170.

Sedangkan pada tahun 2018 Ekonomi Jawa Timur Triwulan I-2018 bila dibandingkan Triwulan I-2017 tumbuh sebesar 5,50\%, meningkat dibandingkan periode yang sama tahun sebelumnya sebesar 5,37\%. Dari sisi produksi, semua kategori mengalami pertumbuhan positif kecuali Kategori Pertanian, Kehutanan dan Perikanan.Pertumbuhan tertinggi terjadi pada Penyediaan Akomodasi dan Makan Minum sebesar 8, 88\%; diikut Konstruksi sebesar 7, $82 \%$. Dari sisi pengeluaran, pertumbuhan tertinggi Pembentukan Modal Tetap Bruto (PMTB) sebesar 5,69\%, diikut Ekspor Luar Negeri sebesar 4,69\%, dan Pengeluaran Konsumsi LNPRT sebesar 4,63\%. Perekonomian Jawa Timur Triwulan II-2018 yang diukur berdasarkan Produk Domesti Regional Bruto (PDRB) atas dasar harga berlaku mencapai Rp 544,44 triliun, sedangkan PDRB atas dasar harga konstan mencapai Rp 388,54 triliun.

Pertumbuhan Perizinan berusaha terhadap sebagai penggerak Perekonomian Daerah Provinsi jawa Timur sebagaimana disebutkan diatas tidak terlepas dari system Perizinan berusaha di daerah provinsi Jawa Timur yang diterapkan Pemerintah Daerah. Secara yuridis sebagai daerah otonom yang berwenang mengatur dan mengurus sendiri pemerintahan daerah berdasarkan asas otonomi dan tugas pembantuan, Pemerintah Daerah Provinsi Jawa Timur, mendasari pengaturan hukum penyelenggaraan penanaman modal di Jawa Timur dengan Peraturan Daerah Provinsi Jawa Timur Nomor 12 Tahun 2013 Tentang Penanaman Modal, agar penyelenggaraan penanaman modal tersebut berkepastian hukum, berjalan dengan efektif dan efisien serta guna menarik minat penanam modal bertujuan memajukan kesejahteraan umum dalam rangka pemerataan pembangunan ekonomi dan perluasan lapangan kerja serta meningkatkan daya saing daerah.

Peraturan Daerah Provinsi Jawa Timur Nomor 12 Tahun 2013 Tentang Penanaman Modal adalah dasar hukum utama di Daerah Provinsi Jawa Timur yang mengatur tentang system perizinan berusaha. Pembentukan Peraturan Daerah ini didasarkan pada pertimbangan bahwa penanaman modal memegang peranan penting dalam meningkatkan pertumbuhan ekonomi di Provinsi Jawa Timur dan secara langsung akan memberikan dampak positif dalam meningkatkan kesejahteraan masyarakat, peningkatan kualitas dan mempercepat peningkatan penanaman modal yang akan mendorong iklim usaha yang kondusif untuk penguatan daya saing perekonomian di Provinsi Jawa Timur.

Pengaturan khusus tentang Perizinan berusaha dalam Peraturan Daerah Provinsi Jawa Timur Nomor 12 Tahun 2013 Tentang Penanaman Modal, dalam ketentuan Pasal 1 angka 16 Peraturan Daerah ini, mendefinisikan bahwa Perizinan adalah segala bentuk persetujuan untuk melakukan penanaman modal yang dikeluarkan oleh Pemerintah Provinsi yang memiliki kewenangan sesuai dengan ketentuan peraturan perundang-undangan. Dalam ketentuan Pasal 10 Peraturan Daerah ini menentukan bahwa Jenis pelayanan penanaman modal dibagi kedalam 3 (tiga) tahapan pelayanan meliputi pelayanan pra perizinan, pelayanan perizinan dan pelayanan pasca perizinan.Pelayanan pra perizinan merupakan kegiatan yang meliputi penyediaan data dan informasi di bidang penanaman modal, fasilitasi dan koordinasi penjajagan penanaman modal dengan pihak terkait dan/atau menjalin kerjasama dalam rangka persiapan penanaman modal. 
Berkaitan dengan Pelayanan Perizinan ini dikehendaki kepada Setiap penanam modal dalam negeri yang akan melakukan kegiatan PMDN di Provinsi wajib memiliki perizinan di bidang penanaman modal yang terdiri atas Izin dan Non Izin. Beberapa jenis Izin di bidang PMDN terdiri dari:

a. izin prinsip penanaman modal;

b. izin prinsip perluasan penanaman modal;

c. izin prinsip perubahan penanaman modal;

d. izin prinsip penggabungan perusahaan penanaman modal;

e. izin usaha;

f. izin usaha perluasan;

g. izin usaha perubahan; dan

h. izin usaha penggabungan perusahaan penanaman modal.

Sedangkan Non Izin di bidang penanaman modal terdiri dari:

a. Angka Pengenal Importir Produsen (API-P);

b. Angka Pengenal Importir Umum (API-U);

c. Perpanjangan Rencana Penggunaan Tenaga Kerja Asing (RPTKA); dan

d. Perpanjangan Izin Mempekerjakan Tenaga Asing (IMTA).

Berdasarkan Peraturan daerah Nomor 12 Tahun 2013 Tentang Penanaman Modal, Perizinan sebagaimana dimaksud diatas ditetapkan oleh Gubernur dan dilimpahkan kepada Kepala Badan UPT P2T dengan menggunakan Sistem Pelayanan Informasi dan Perizinan Investasi Secara Elektronik (SPIPISE) yang terintegrasi dengan Pemerintah dan Pemerintah Kabupaten/ Kota.

Sedangkan terhadap Pelayanan Pasca Perizinan dilakukan dalam berbagai kegiatan meliputi:

a. bimbingan pelaksanaan pelaporan kegiatan penanaman modal;

b. fasilitasi dan koordinasi penyelesaian masalah pelaksanaan penanaman modal;

c. fasilitasi penyediaan lahan usaha;

d. fasilitasi ketenagakerjaan dan hubungan industrial; dan/atau

e. fasilitasi penyediaan energi.

Sistem Pelayanan Informasi dan Perizinan Investasi Secara Elektronik (SPIPISE) adalah sistem pelayanan perizinan dan non perizinan yang terintegrasi antara Pemerintah dengan Pemerintah Provinsi dan Pemerintah Kabupaten/Kota.Pengelolaan Data dan Pengembangan Sistem Informasi Penanaman Modal dilaksanakan secara terintegrasi berbasis SPIPISE dengan Pemerintah dan Pemerintah Kabupaten/Kota.Dimana Pengelolaan data di bidang penanaman modal meliputi pengumpulan, pengolahan dan penyajian.Pengembangan sistem informasi di bidang penanaman modal meliputi pengembangan website pengembangan database dan sistem informasi yang terintegrasi.

Sebagai pelaksana Peraturan Daerah Provinsi Jawa Timur Nomor 12 Tahun 2013 Tentang Penanaman Modal, Pemerintah Daerah/ Gubernur Provinsi Jawa Timur menerbitkan Peraturan Gubernur Jawa Timur Peraturan Gubernur Jawa Timur Nomor 8 Tahun 2015 Tentang Perubahan Atas Peraturan GubernurJawa Timur Nomor 77 Tahun 2010 Tentang Penyelenggaraan Pelayanan Perizinan Terpadu. Peraturan Gubernur ini dibentuk dalam rangka meningkatkan kualitas pelayanan publik di bidang perizinan yang cepat, efektif, efisien dan transparan perlu dilaksanakan penyelenggaraan pelayanan perizinan terpadu.Dalam ketentuan Pasal 4 dinyatakan bahwa Penyelenggaraan P2T secara administrasi dilaksanakan oleh Unit Penyelenggara Pelayanan Perizinan Terpadu dibawah koordinasi Badan Penanaman Modal. Dimana Penerbitan atau penolakan surat izin di Unit Penyelenggara P2T dilaksanakan dan ditandatangani oleh Administrator yang ditunjuk dan diangkat oleh Gubernur. Unit Penyelenggaraan P2T mempunyai tugas pokok membantu dan bertanggung jawab kepada 
Kepala Badan Penanaman Modal dalam menyelenggarakan administrasi perizinan Dan mempunyai fungsi pelaksanaan administrasi pelayanan perizinan dan pengkoordinasian penyelenggaraan administrasi pelayanan perizinan.

Selain itu dalam Peraturan Gubernur ini ditentukan berbagai Jenis Perizinan yang diterbitkan oleh Pemerintah Daerah Provinsi Jawa Timur di Unit Penyelenggara P2T, meliputi sektorsektor:
a. Perencanaan dan Pembangu- nan Daerah
b. Penanaman Modal
c. Kesehatan
d. Pekerjaan Umum Bina Marga
e. Pekerjaan Umum Pengairan
f. Perhubungan dan LLAJ
g. Sosial
h. Ketenagakerjaan

i. Koperasi dan UMKM

j. Kebudayaan dan Pariwisata

k. Pertanian

1. Peternakan

m. Perikanan dan Kelautan

n. Kehutanan

o. Energi dan Sumberdaya Mineral

p. Perindustrian dan Perdagangan

q. Lingkungan Hidup

Akibat Hukum ditetapkannya Peraturan Pemerintah Nomor 24 Tahun 2018 Tentang Pelayanan Perizinan Berusaha Terintegrasi Secara Elektronik dengan Penyelengaraan Penanaman Modal di Daerah Provinsi Jawa Timur, sebagaimana didasarkan pada Peraturan Daerah Provinsi Jawa Timur Nomor 12 Tahun 2013 Tentang Penanaman Modal Sebagai Dasar hukum Perizinan Berusaha Di Daerah Provinsi Jawa Timur, diketahui bahwa secara komprehensif terdapat pertentangan dan perbedaan pengaturan tentang sistem Pelayanan perizinan berusaha diantara ke-2 (kedua) jenis peraturan perundang undangan tersebut.

Dengan mengingat bahwa Peraturan Pemerintah Nomor 24 Tahun 2018 dibentuk atas dasar Penyempurnaan regulasi Pelayanan Perizinan Berusaha di Indonesia, meliputi jenis, pemohon, dan penerbit Perizinan Berusaha, pelaksanaan Perizinan Berusaha, reformasi Perizinan Berusaha sektor, sistem OSS, Lembaga OSS, pendanaan OSS, insentif atau disinsentif pelaksanaan Perizinan Berusaha melalui OSS dan penyelesaian permasalahan dan hambatan Perizinan Berusaha melalui OSS Sebagaimana diuraikan sebelumnya. Maka Peraturan daerah Provinsi Jawa Timur Nomor 12 Tahun 2013 Tentang Penanaman Modal beserta peraturan Pelaksanaannya seperti Peraturan Gubernur Jawa Timur Peraturan Gubernur Jawa Timur Nomor 8 Tahun 2015 Tentang Perubahan Atas Peraturan Gubernur Jawa Timur Nomor 77 Tahun 2010 Tentang Penyelenggaraan Pelayanan Perizinan Terpadu, harus disesuaikan pengaturanya dengan Peraturan Pemerintah Nomor 24 Tahun 2018 Tentang Pelayanan Perizinan terintegrasi Secara elektronik.

Berkaitan dengan mekanisme pengawasan refresif sebelum terbitnya Putusan Mahkamah Konstitusi Nomor 56/PUU-XIV/2016 tentang pencabutan kewenangan Pemerintah Pusat untuk membatalkan (executive review) Peraturan Daerah Provinsi. Berdasarkan pada Pasal 251 Undang Undang Nomor 23 Tahun 2014, secara khusus mengatur mengenai Pembatalan Peraturan Daerah, dimana Kementerian Dalam Negeri (Kemendagri) dinyatakan berwenang membatalkan Peraturan Daerah Provinsi yang bertentangan dengan ketentuan Peraturan Perundang-undangan yang lebih tinggi, kepentingan umum, dan/atau kesusilaan. Pembatalan Peraturan Daerah Provinsi tersebut ditetapkan dengan keputusan menteri, untuk kemudian paling lama 7 (tujuh) hari setelah keputusan pembatalan Peraturan Daerah, kepala daerah harus menghentikan pelaksanaan Peraturan Daerah dan Selanjutnya DPRD bersama Kepala Daerah mencabut Peraturan Daerah dimaksud. Dan bilamana dalam hal penyelenggara Pemerintahan Daerah Provinsi tidak dapat menerima keputusan pembatalan Peraturan Daerah Provinsi dan 
Gubernur dengan alasan yang dapat dibenarkan oleh ketentuan Peraturan Perundang-undangan, Gubernur dapat mengajukan keberatan kepada Presiden paling lambat 14 (empat belas) Hari sejak keputusan pembatalan Peraturan Daerah atau Peraturan Gubernur diterima.

Bilamana Penyelenggara Pemerintahan Daerah Provinsi masih memberlakukan Peraturan Daerah yang dibatalkan oleh Menteri dikenai sanksi berupa sanksi administratif; dan/atau sanksi penundaan evaluasi rancangan Peraturan Daerah.Sanksi administratif dikenakan kepada kepala Daerah dan anggota DPRD berupa tidak dibayarkan hak-hak keuangan yang diatur dalam ketentuan peraturan perundang-undangan selama 3 (tiga) bulan.Sementara Sanksi penundaan evaluasi rancangan Peraturan Daerah tidak diterapkan pada saat penyelenggara Pemerintahan Daerah masih mengajukan keberatan kepada Presiden untuk Peraturan Daerah Provinsi.Kemudian apabila dalam hal penyelenggara Pemerintahan Daerah provinsi masih memberlakukan Peraturan Daerah mengenai pajak daerah dan/atau retribusi daerah yang dibatalkan oleh Menteri, dikenai sanksi penundaan atau pemotongan DAU dan/atau DBH bagi Daerah bersangkutan.

Namun setelah terbitnya Putusan Mahkamah Konstitusi Nomor 56/PUU-XIV/2016 tentang pencabutan kewenangan Pemerintah Pusat untuk membatalkan Peraturan Daerah Provinsi. Maka Pemerintah Pusat melalui kementerian Dalam Negeri tidak lagi berwenang melakukan pengawasan Peraturan Daerah Provinsi secara Refresif melalui mekanisme eksekutif review sehingga kewenangan Pembatalan/pencabutan Peraturan Daerah Provinsi melalui system pengawasan secara Refresif, melalui mekanisme yudicial review hanya dimiliki oleh Mahkamah Agung.

Berdasarkan ketentuan Pasal 31 ayat (2) Undang Undang Nomor 5 Tahun 2004 sebagaimana diubah dengan UndangUndang Nomor 3 Tahun 2009 Tentang Mahkamah Agung menyatakan bahwa:

a. Mahkamah Agung mempunyai wewenang menguji peraturan perundang-undangan di bawah undang-undang terhadap undang undang.

b. Mahkamah Agung menyatakan tidak sah peraturan perundang-undangan di bawah undangundang atas alasan bertentangan dengan peraturan perundang-undangan yang lebih tinggi atau pembentukannya tidak memenuhi ketentuan yang berlaku.

c. Putusan mengenai tidak sahnya peraturan perundang-undangan sebagaimana dimaksud pada ayat (2) dapat diambil baik berhubungan dengan pemeriksaan pada tingkat kasasi maupun berdasarkan permohonan langsung pada Mahkamah Agung.

d. Peraturan perundang-undangan yang dinyatakan tidak sah sebagaimana dimaksud pada ayat (3) tidak mempunyai kekuatan hukum mengikat.

e. Putusan sebagaimana dimaksud pada ayat (3) wajib dimuat dalam Berita Negara Republik Indonesia dalamjangka waktu palinglambat30(tiga puluh)harikerja sejak putusan diucapkan. Sedangkan dalam menjalankan kewenangan pengujian peraturan perundang-undangan, Mahkamah Agung menggunakan Peraturan Mahkamah Agung Nomor 1 Tahun 2011 Tentang Hak Uji Materiil.

Pemerintah Pusat sebagai pembina dan pengawas Penyelenggaran Pemerintahan Daerah tetap memiliki andil dalam pengawasan Peraturan Daerah. Pengawasan tersebut dilakukan melalui mekanisme evaluasi dan pemberian nomor register rancangan Peraturan Daerah. Sebagaimana diatur dalam ketentuan Pasal Pasal 242 Undang Undang Nomor 23 Tahun 2014. Secara substansial dinyatakan bahwa Rancangan Perda yang telah disetujui bersama oleh DPRD dan Kepala Daerah disampaikan oleh pimpinan DPRD kepada kepala daerah untuk ditetapkan menjadi Perda dilakukan dalam jangka waktu paling lama 3 (tiga) Hari terhitung sejak tanggal persetujuan bersama. Dan Gubernur wajib menyampaikan rancangan Perda 
Provinsi kepada Menteri paling lama 3 (tiga) Hari terhitung sejak menerima rancangan Perda Provinsi dari pimpinan DPRD Provinsi untuk mendapatkan nomor register Perda. Rancangan Perda yang belum mendapatkan nomor register belum dapat ditetapkan kepala Daerah dan belum dapat diundangkan dalam lembaran daerah.

Dengan demikian berdasarkan pada ketentuan Pasal 7 ayat (2)Undang Undang Nomor 12 Tahun 2011, bahwa pengakuan keberadaan dan kekuatan hukum mengikat suatu peraturan perundang undangan didasarkan pada hierarkinya. Maka Peraturan Daerah Provinsi Jawa Timur Nomor 12 Tahun 2013 Tentang Penanaman Modal beserta Pelaturan Pelaksanaanya seperti Peraturan Gubernur Jawa Timur Peraturan Gubernur Jawa Timur Nomor 8 Tahun 2015 Tentang Perubahan Atas Peraturan Gubernurjawa Timur Nomor 77 Tahun 2010 Tentang Penyelenggaraan Pelayanan Perizinan Terpadu, tidak boleh mengandung materi muatan yang bertentangan dengan Peraturan Pemerintah Nomor 24 Tahun 2018 Tentang Pelayanan Perizinan terintegrasi secara Elektronik. Sebagaimana dikatahui berdasarkan pada uraian sebelumnya bahwa Peraturan Daerah Provinsi Jawa Timur Nomor 12 Tahun 2013 Tentang Penanaman Modal mengatur materi muatan yang tidak sesuai dengan Peraturan Pemerintah Nomor 24 Tahun 2018 Tentang Pelayanan Perizinan terintegrasi secara Elektronik, sehingga Pemerintah Daerah Provinsi Jawa Timur dan DPRD Jawa Timur perlu melakukan penggantian atau Perubahan terhadap Peraturan Daerah Provinsi Jawa Timur Nomor 12 Tahun 2013 Tentang Penanaman Modal.

Undang Undang Nomor 12 Tahun 2011, memberikan alternatip pnyesuaian suatu peraturan perundang undangan yang bertentangan dengan Peraturan perundangan yang berkedudukan diatasnya termasuk terhadap Peraturan Daerah Provinsi Jawa Timur Nomor 12 Tahun 2013 Tentang Penanaman Modal. Alternatip tersebut dapat dilakukan melalui 2 (dua) cara yakni pembentukan Peraturan Daerah Provinsi jawa Timur baru tentang Perubahan Peraturan Daerah Provinsi Jawa Timur Nomor 12 Tahun 2013 Tentang Penanaman Modal dan Pembentukan Peraturan Daerah Provinsi Daerah Jawa Timur tentang Penanaman Modal baru sebagai pengganti dari Peraturan Daerah Provinsi Jawa Timur Nomor 12 Tahun 2013 Tentang Penanaman Modal. Kemudian akan diikuti dengan perubahan/pencabutanPeraturan Gubernur Jawa Timur Nomor 8 Tahun 2015 Tentang Perubahan Atas Peraturan Gubernur Jawa Timur Nomor 77 Tahun 2010 Tentang Penyelenggaraan Pelayanan Perizinan Terpadu.

Perubahan Peraturan Perundang-undangan dilakukan dengan menyisip atau menambah materi ke dalam Peraturan Perundang undangan atau menghapus atau mengganti sebagian materi Peraturan Perundang undangan. Jika suatu perubahan Peraturan Perundang-undangan mengakibatkan sistematika Peraturan Perundang-undangan berubah materi Peraturan Perundang-undangan berubah lebih dari 50\% (lima puluh persen) atau esensinya berubah, Peraturan Perundang-undangan yang diubah tersebut lebih baik dicabut dan disusun kembali dalam Peraturan Perundang-undangan yang baru mengenai masalah tersebut.

\section{KESIMPULAN}

Keberadaan Peraturan Pemerintah Nomor 24 Tahun 2018 untuk memberikan pelayanan yang cepat dan teriktegrasi dalam satu payung hukum untuk mempercepat proses pelayanan perizinan berusaha secara elektonik. Dengan adanya peraturan pemerintah tersebut untuk membantu penyelarasan bagi Pemerintah Daerah (Provinsi Jawa Timur) dalam memberikan pelayanan perizinan berusaha berbasis elektronik. 


\section{DAFTAR PUSTAKA}

Bank Indonesia. (2018). Pertumbuhan Ekonomi. Jakarta.

LPEM FEB UI. (2018). Seri Analisis Makroekonomi Indonesia Economic Outlook. Jakarta.

Laporan Keterangan Pertanggungjawaban Gubernur Kepada DPRD Provinsi Jawa Timur Akhir Tahun Anggaran 2017.

Rencana Pembangunan Jangka Menengah Nasional 2015-2019.

Rencana Strategis Badan Koordinasi Penanaman Modal Tahun 2015-2019.

Seri Analisis Makroekonomi Indonesia Economic Outlook 2018

Undang Undang Nomor 12 Tahun 2011 Tentang Pembentukan Peraturan Perundang-undangan, Lembaran Negara Republik Indonesia Tahun 2011 Nomor 82. 